\title{
Research on Performance Evaluation of Light Assets Operation of Real Estate Enterprises Based on Balanced Scorecard
}

\author{
Yu Luo \\ School of Economics and Management \\ Beijing Jiaotong University \\ Beijing, China
}

\author{
Yan Liu \\ School of Economics and Management \\ Beijing Jiaotong University \\ Beijing, China
}

\begin{abstract}
Nowadays, China's real estate enterprises are beginning to change in the operation mode, from the traditional heavy asset operation mode to the light asset operation mode. The impact of the light asset operation model on business operations requires us to evaluate the performance of real estate companies under the light asset operation model. This article first explores the current situation of China's real estate enterprises in light asset operations. On this basis, the specific indicators under the four dimensions of the balanced scorecard are determined, and the performance evaluation model of China's real estate enterprises' light assets is constructed. Finally, using the W company of the light asset operation mode as a case, the questionnaire survey method is used to obtain the evaluation results of different indicators. Through analysis and processing, the W18 Company's annual performance evaluation results are obtained, and the evaluation results are analyzed to propose the W company's light asset operation optimization recommendations.
\end{abstract}

Keywords-light asset operation; real estate enterprise; performance evaluation; balanced scorecard

\section{INTRODUCTION}

The concept of "light assets" was first proposed by foreign scholar Wernerfelt. Based on the theory of "resource view", he positioned "light assets" as special resources, which are rich in value, relatively scarce, and unable to replicate. The effective integration of resources contributes the greatest value [1]. At the same time, Amit has identified the content of these unique resources through research on light assets, including corporate customer relationships, intellectual property, channel networks, including patents, manpower, rental culture, corporate values and management systems, including Some intangible assets, such as innovation ability, research and development capabilities and corporate marketing level [2].

Domestic scholars have also put forward a lot of research on "light assets". Sun Li and Zhu Wuxiang define the concept of light assets from the use of funds. They think that the company's factories, machinery and equipment, production materials, etc often require enterprises to invest a lot of money, and enterprises. The intangible assets of brand value, customer relationship maintenance, talent echelon construction, management experience and internal processes do not require the company to invest a large amount of capital, so the latter is called light assets [3]. Xu Chunyou pointed out that the company's light assets should include management experience, brand value, corporate values, process control, associated resources with the outside world, customer maintenance and human resources [4].

Although scholars at home and abroad express different opinions, the substantive content is similar. In summary, light assets are actually a type of assets relative to heavy assets, generally referring to the brand value, relationship resources, management systems and processes, human resources, corporate culture, etc.

\section{Current Status of Light Assets Operation of REAL ESTATE ENTERPRISES IN CHINA}

At present, many real estate companies are trying to operate the light asset model. Real estate companies such as Wanda, Vanke, Greentown and China Resources Land have launched light asset management projects. At present, China's real estate enterprises have the following four modes when conducting light asset operations [5]: (1) Cooperative development: Cooperative development refers to the cooperation between real estate companies and partners to jointly develop and construct real estate projects. When conducting cooperative development, there are mainly two types of small-scale trading and cooperative land acquisition. (2) Sale of equity: Under this model, part or all of the equity held by the real estate enterprise is sold, but it is still responsible for the subsequent development and operation management of the project, and collects equity income and management fees. (3) Real estate + fund: As a capital-intensive industry, the real estate industry itself cannot be separated from finance. In recent years, more and more real estate companies in China have tried to open up new channels for real estate financing through the establishment of private equity investment funds or trust investment funds. (4) Output brand and management: Under this model, real estate companies basically do not invest funds, mainly through the export of brands and management to obtain income, and collect management fees. 
First of all, in terms of profitability, this paper selects two

III. ESTABLISHMENT OF PERFORMANCE EVALUATION MODEL FOR LIGHT ASSET OPERATION OF REAL ESTATE ENTERPRISES BASED ON BALANCED SCORECARD

\section{A. The Meaning of the Balanced Scorecard}

The concept of the Balanced Scorecard is proposed by Kaplan and Norton. It is a performance evaluation method based on the long-term development strategy of the enterprise. The key to a balanced scorecard is to clarify specific implementation measures based on the overall strategic goals of the enterprise, and finally achieve the ultimate goal of the business [6]. Therefore, the Balanced Scorecard is both a performance evaluation method and a strategic management tool. The Balanced Scorecard believes that the traditional performance evaluation only analyzes and evaluates the past business results, and cannot measure the impact of the intangible assets of the company's future value and competitive advantage on the enterprise [7]. In the era of focusing on economic development in the past, it is feasible to focus on the financial aspect of the company when performing performance evaluation. However, in the full informationization, enterprises must take into account the development of customers, management systems, innovative technologies, etc., so the balanced scorecard believes that enterprises should conduct performance evaluation from the following four aspects: finance, customers, internal management processes, learning and growth [8].

\section{B. Balanced Scorecard Index System Construction Ideas}

Balanced scorecard is not only a strategic management tool, but also a performance evaluation method. Firstly, as a strategic management tool, when applying the balanced scorecard to evaluate the performance of real estate enterprises' light asset operations, it is necessary to closely integrate enterprises to implement light assets. The planning of the operational strategy, that is, the selection of specific indicators under the four dimensions, should reflect the purpose of real estate enterprises to implement the light asset operation strategy [9].In addition, as a performance evaluation method, when using the balanced scorecard, it is necessary to combine the characteristics of real estate enterprises. The real estate industry is different from other industries and has its own distinctive characteristics, especially in the internal management process dimension. The characteristics of the development project can be selected by indicators such as project schedule and project quality to evaluate its performance, and truly reflect the operational results of the company [10].

\section{Indicator Selection}

According to the above construction ideas and index selection principles, we can select the indicators under each dimension, the specific process is as follows:

1) Financial dimension indicators: The financial dimension indicator is to assess the economic operating results of the company, which is designed to maximize the interests of shareholders. The financial dimension indicators generally include four levels: profitability, asset operation, solvency, and growth ability. Under these four levels, specific indicators are selected for evaluation. representative indicators of sales net profit margin and cost expense profit rate. The net profit margin is calculated by calculating the proportion of net profit in total sales revenue, measuring how much profit can be created per yuan, and showing the overall profit level of the company. The cost and profit margin is the ratio of the operating profit and the total cost of the enterprise at one stage, reflecting the profit benefit of the enterprise's cost per unit and fully reflecting the economic benefits of the enterprise.

In terms of asset operation, this paper selects the total asset turnover rate, and the total asset turnover rate calculates the proportion of sales revenue in the total assets of the enterprise, and comprehensively reflects the efficiency of the enterprise's utilization of funds.

In terms of solvency, this paper selects the asset-liability ratio, which is the ratio of total liabilities to total assets. For real estate enterprises, the investment amount is high and the investment recovery period is long, and the debt ratio is much higher than other industries. Therefore, the lower the debt ratio is, the better the business performance of the enterprise will be.

In terms of growth capacity, this paper selects the sales revenue growth rate. The sales revenue growth rate is a comparison between the sales revenue of the current year and the sales revenue of the previous year to measure the change in sales revenue. The higher the sales revenue growth rate is, the stronger the company's growth ability will be.

In summary, the Balanced Scorecard not only retains some of the original traditional financial performance indicators, but also focuses on the characteristics of light asset operations, and increases the indicators that mainly affect the performance of enterprises under the light asset operation trend. Through these indicators, we can jointly measure the operating results of enterprises in financial aspects. Therefore, the evaluation indicators of the financial dimension are shown in "Table I":

TABLE I. INDICATORS OF FINANCIAL DIMENSION

\begin{tabular}{|c|c|c|}
\hline $\begin{array}{l}\text { Evaluation } \\
\text { dimension }\end{array}$ & $\begin{array}{l}\text { Evaluation } \\
\text { index }\end{array}$ & Calculation method \\
\hline \multirow{6}{*}{$\begin{array}{l}\text { Financial } \\
\text { dimension }\end{array}$} & $\begin{array}{l}\text { Total asset } \\
\text { turnover }\end{array}$ & Sales revenue / total assets \\
\hline & $\begin{array}{l}\text { Sales revenue } \\
\text { growth rate }\end{array}$ & $\begin{array}{l}\text { This year's sales revenue - } \\
\text { sales revenue of the previous } \\
\text { year) / sales revenue of the } \\
\text { previous year }\end{array}$ \\
\hline & Sales margin & $\begin{array}{l}\text { Net profit / sales income * } \\
100 \%\end{array}$ \\
\hline & $\begin{array}{l}\text { Cost cost profit } \\
\text { margin }\end{array}$ & Operating profit/cost total \\
\hline & $\begin{array}{l}\text { Assets and } \\
\text { liabilities }\end{array}$ & $\begin{array}{l}\text { Total liabilities / total assets * } \\
100 \%\end{array}$ \\
\hline & Fixed asset ratio & Fixed assets/total assets \\
\hline
\end{tabular}

2) Customer dimensional indicators: The realization of corporate value is ultimately achieved through the customer, and the customer is the main source of corporate profits. At the customer level, real estate enterprises mainly aim to increase market share, improve customer satisfaction through quality products and service quality, and promote the 
and planned days of the project. The difference between the two is used to reflect the company's progress control ability; the project quality and good rate refers to the ratio of the project quality and the total number of projects to evaluate the company's ability to control the quality of the project; in the sales phase, due to the indicators for evaluating sales have been reflected in the financial dimension. Therefore, in the postsales phase of the project, the owner's complaint resolution rate is selected to measure the post-sales level of the real estate enterprise. The owner's complaint resolution rate refers to the proportion of the number of complaints from the owners to the total number of complaints from the owners, mainly reflecting the company's ability to handle complaints.

In addition, for the large internal management process of real estate enterprises, it is very important to have a set of scientific standard management system, especially in the light asset operation mode, the enterprise will operate the light assets through direct output management, if there is no scientific and mature management. The system not only affects the level of business operations and management, but also damages the brand reputation of the company. In summary, the evaluation indicators of the internal management process dimension are shown in "Table III":

TABLE III. INDICATORS OF INTERNAL OPERATIONAL PROCESS DIMENSION

\begin{tabular}{|c|c|c|}
\hline $\begin{array}{l}\text { Evaluation } \\
\text { dimension }\end{array}$ & $\begin{array}{l}\text { Evaluation } \\
\text { index }\end{array}$ & Calculation method \\
\hline \multirow{6}{*}{$\begin{array}{l}\text { Internal } \\
\text { management } \\
\text { process }\end{array}$} & $\begin{array}{l}\text { Relationship } \\
\text { resource }\end{array}$ & I \\
\hline & $\begin{array}{l}\text { Project } \\
\text { development } \\
\text { planning }\end{array}$ & I \\
\hline & $\begin{array}{l}\text { Project } \\
\text { schedule } \\
\text { deviation }\end{array}$ & $\begin{array}{l}\text { Actual project progress days - } \\
\text { planned days }\end{array}$ \\
\hline & $\begin{array}{l}\text { Project quality } \\
\text { and good rate }\end{array}$ & $\begin{array}{l}\text { Excellent engineering quality / total } \\
\text { number of projects }\end{array}$ \\
\hline & $\begin{array}{l}\text { Owner } \\
\text { complaint } \\
\text { resolution rate }\end{array}$ & $\begin{array}{l}\text { Resolve the number of complaints } \\
\text { from owners/number of complaints } \\
\text { from owners* } 100 \%\end{array}$ \\
\hline & $\begin{array}{l}\text { Management } \\
\text { System }\end{array}$ & I \\
\hline
\end{tabular}

4) Learning and growth dimensions: Only by continuously strengthening the construction of all aspects of the enterprise can the company promote the efficiency of the internal operation of the enterprise and achieve the goals of the financial dimension and the customer dimension. Under the trend of light asset operation, the human resources, information level and corporate culture of enterprises are particularly important.

In terms of human resources, enterprises should pay attention to the cultivation and introduction of talents, strengthen the talent pool, and improve the overall quality of employees. This paper selects the key job turnover rate and the proportion of employee training. The key job turnover rate refers to the proportion of key job loss to the total number of key positions, which is a reflection of the ability of enterprises to retain their talents; the proportion of employee training can further show the proportion of employees participating in the 
TABLE IV. INDICATORS OF LEARNING AND GROWING UP DIMENSION

training among the overall employees, which can be clearly It reflects the degree to which the company trains its employees.

In the aspect of information systems, improve the information system and build a complete database to improve the overall operational efficiency of the enterprise. This paper selects the completion rate of the information system construction plan.

In terms of corporate culture, we attach great importance to the construction of corporate culture and build a corporate culture that is conducive to the sustainable development of enterprises, so that employees can have a good corporate culture. This paper selects corporate culture satisfaction. Corporate culture satisfaction is an evaluation index centered on corporate culture. Therefore, the evaluation indicators of the enterprise learning and growth dimension are shown in "Table IV":

\begin{tabular}{|c|c|c|}
\hline $\begin{array}{c}\text { Evaluation } \\
\text { dimension }\end{array}$ & Evaluation index & Calculation method \\
\hline \multirow{4}{*}{$\begin{array}{l}\text { Learning } \\
\text { and growth }\end{array}$} & Key job churn rate & $\begin{array}{l}\text { Number of key positions lost } \\
/ \text { total number of key } \\
\text { positions } * 100 \%\end{array}$ \\
\hline & $\begin{array}{l}\text { Employee training } \\
\text { ratio }\end{array}$ & $\begin{array}{l}\text { Number of participants / total } \\
\text { number of employees } * 100 \%\end{array}$ \\
\hline & $\begin{array}{l}\text { Information } \\
\text { system } \\
\text { construction plan } \\
\text { completion rate }\end{array}$ & $\begin{array}{l}\text { Number of actual completed } \\
\text { projects/planned projects in } \\
\text { information } \\
\text { construction }\end{array}$ \\
\hline & $\begin{array}{l}\text { Corporate culture } \\
\text { satisfaction }\end{array}$ & survey \\
\hline
\end{tabular}

Through the above analysis, it can be concluded that under the light asset operation mode, the performance evaluation index system of real estate enterprises is shown in "Table V":

TABLE V. BALANCED SCORECARD INDICATOR SYSTEM

\begin{tabular}{|c|c|c|}
\hline Target layer A & Criteria layer B & Indicator layer $\mathbf{C}$ \\
\hline \multirow{19}{*}{$\begin{array}{l}\text { Performance Evaluation System for Real } \\
\text { Estate Enterprises Under the Trend of } \\
\text { Light Assets Operation }\end{array}$} & \multirow{6}{*}{ Financial dimension B1 } & Total asset turnover rate $\mathrm{C} 1$ \\
\hline & & Sales revenue growth rate $\mathrm{C} 2$ \\
\hline & & Net sales rate $\mathrm{C} 3$ \\
\hline & & Cost and profit margin $\mathrm{C} 4$ \\
\hline & & Asset-liability ratio C5 \\
\hline & & Fixed asset ratio C6 \\
\hline & \multirow{4}{*}{ Customer dimension B2 } & Market share C7 \\
\hline & & Customer Satisfaction C9 \\
\hline & & Customer growth rate $\mathrm{C} 10$ \\
\hline & & Customer profitability $\mathrm{C} 11$ \\
\hline & \multirow{5}{*}{$\begin{array}{l}\text { Internal management process dimension } \\
\text { B3 }\end{array}$} & Relationship resource C12 \\
\hline & & Project development planning C13 \\
\hline & & Project schedule deviation $\mathrm{C} 14$ \\
\hline & & Project quality and good rate $\mathrm{C} 15$ \\
\hline & & Owner complaint resolution rate $\mathrm{C} 16$ \\
\hline & \multirow{4}{*}{ Learning and Growth Dimension B4 } & Key job turnover rate $\mathrm{C} 18$ \\
\hline & & Staff training ratio $\mathrm{C} 19$ \\
\hline & & Information system construction plan completion rate $\mathrm{C} 20$ \\
\hline & & Corporate Culture Satisfaction C21 \\
\hline
\end{tabular}

\section{Selection of Comprehensive Evaluation Methods}

Factor analysis method, fuzzy comprehensive evaluation method and grey relational analysis method are all methods for comprehensive evaluation. Based on the actual situation of selected indicators, the fuzzy comprehensive evaluation method is adopted.

The fuzzy comprehensive evaluation method is a mathematical subject analysis method. It mainly uses fuzzy relations to deal with some factors that are difficult to quantify. Through the separation and evaluation of multiple factors, the comprehensive evaluation of the evaluation objects is completed. The specific process of comprehensive evaluation of enterprise performance by applying fuzzy comprehensive evaluation method is:

- Determining the factor set $\mathrm{U}$ of the evaluation object

The set of hypothetical factors is $U=\{u 1, u 2, \ldots u n\}$, and the factor set is the index in the enterprise performance evaluation system. The factor set in this paper is the set of indicators at different levels.

- Determining the comment set of the evaluation object $\mathrm{V}$

It is assumed that the comment set is $\mathrm{V}=\{\mathrm{v} 1, \mathrm{v} 2, \ldots$ $\mathrm{vm}$, which is a collection of comments composed by the evaluator on the rating result of the object to be evaluated. The collection of reviews is generally pre-set, generally excellent, good, qualified, unqualified, etc.

- Comprehensive evaluation, calculation of comprehensive evaluation value $\mathrm{E}$

The evaluation matrix $\mathrm{B}$ of the enterprise performance can be calculated by the formula $\mathrm{B}=\mathrm{W} * \mathrm{R}$. The evaluation set assigned to each evaluation level is represented by $H=\{h 1$, $\mathrm{h} 2, \ldots \mathrm{hm}\}$, and the comprehensive evaluation result is calculated by the formula $\mathrm{E}=\mathrm{B} * \mathrm{HT}$, and the evaluation level of the index is further determined. 
factors, and 46 valid questionnaires were obtained through screening.

2) Data analysis and processing: After sorting out the results of the effective questionnaire, the evaluation of the indicators is shown in "Table VI":

\section{A. W Company Light Asset Operation Performance Evaluation}

1) Questionnaire: In the 50 questionnaires actually distributed, 48 cases were actually recovered due to objective

TABLE VI. ThE RESUlTS OF STATISTICS

\begin{tabular}{|l|l|l|l|l|}
\hline \multirow{2}{*}{ Indicator layer } & \multicolumn{4}{c|}{ Different grades } \\
\cline { 2 - 5 } & Excellent & Good & Qualified & Failed \\
\hline Total asset turnover & 24 & 15 & 5 & 2 \\
\hline Sales revenue growth rate & 30 & 15 & 1 & 0 \\
\hline Sales margin & 12 & 10 & 20 & 4 \\
\hline Cost cost profit margin & 11 & 11 & 18 & 6 \\
\hline Assets and liabilities & 18 & 10 & 14 & 4 \\
\hline Fixed asset ratio & 13 & 13 & 14 & 6 \\
\hline Market share & 20 & 20 & 6 & 0 \\
\hline Number of branding activities & 18 & 22 & 6 & 0 \\
\hline Customer satisfaction & 33 & 8 & 4 & 1 \\
\hline Customer growth rate & 19 & 10 & 13 & 4 \\
\hline Customer profitability & 28 & 7 & 7 & 4 \\
\hline Relationship resource & 20 & 15 & 10 & 1 \\
\hline Project development planning & 25 & 14 & 5 & 2 \\
\hline Project schedule deviation & 15 & 23 & 4 & 4 \\
\hline Project quality and good rate & 15 & 15 & 10 & 6 \\
\hline Owner complaint resolution rate & 15 & 11 & 14 & 6 \\
\hline Management system & 21 & 16 & 8 & 1 \\
\hline Key job churn rate & 27 & 10 & 5 & 4 \\
\hline Employee training ratio & 13 & 15 & 13 & 5 \\
\hline Information system construction plan completion rate & 18 & 15 & 8 & 5 \\
\hline Corporate culture satisfaction & 18 & 18 & 8 & 2 \\
\hline
\end{tabular}

The evaluation set of this paper is $\mathrm{V}=$ \{excellent, good, qualified, unqualified $\}$, and is assigned to different grades, namely $\mathrm{H}=\{95,80,65,50\}$.The "excellent" is 90 points and above, the "good" is $80-90$ points, the qualified is $60-80$ points, and the "unqualified" is 60 points and below. Taking the total asset turnover rate as an example, the comprehensive evaluation value is $\mathrm{E}=(95 * 24+80 * 15+65 * 5+50 * 2) / 46=84$, indicating that the evaluation level of the total asset turnover rate is "good". Through this calculation method, the evaluation value corresponding to each index and the evaluation level can be obtained. The evaluation results of each indicator level indicator are shown in "Table VII":

TABLE VII. INDICATOR LAYER EVALUATION RESULTS

\begin{tabular}{|c|c|c|c|}
\hline Criteria layer & Indicator layer & Comprehensive evaluation value & Comprehensive evaluation level \\
\hline \multirow{6}{*}{ Finance } & Total asset turnover & 82 & good \\
\hline & Sales revenue growth rate & 90 & excellent \\
\hline & Sales margin & 73 & qualified \\
\hline & Cost cost profit margin & 74 & qualified \\
\hline & Assets and liabilities & 78 & qualified \\
\hline & Fixed asset ratio & 76 & qualified \\
\hline \multirow{5}{*}{ customer } & Market share & 93 & excellent \\
\hline & Number of branding activities & 81 & good \\
\hline & Customer satisfaction & 82 & good \\
\hline & Customer growth rate & 79 & qualified \\
\hline & Customer profitability & 84 & good \\
\hline \multirow{6}{*}{$\begin{array}{l}\text { Internal } \\
\text { process }\end{array}$} & Relationship resource & 83 & good \\
\hline & Project development planning & 86 & good \\
\hline & Project schedule deviation & 81 & good \\
\hline & Project quality and good rate & 73 & qualified \\
\hline & Owner complaint resolution rate & 74 & qualified \\
\hline & Management System & 84 & good \\
\hline \multirow{4}{*}{ Learning and growth } & Key job churn rate & 82 & good \\
\hline & Employee training ratio & 78 & qualified \\
\hline & $\begin{array}{l}\text { Information system construction plan } \\
\text { completion rate }\end{array}$ & 80 & good \\
\hline & Corporate culture satisfaction & 92 & good \\
\hline
\end{tabular}




\section{CONCLUSION}

3) Analysis of evaluation results: From the comprehensive evaluation results of the above-mentioned enterprise performance, it can be seen that the overall performance of $\mathrm{W}$ company is good, indicating that under the light asset operation mode, the enterprise's management level is at the upper middle level, but there is still much room for improvement. The four dimensions of the card are a detailed analysis of $\mathrm{W}$ company performance evaluation results:

a) Financial dimension: In the performance evaluation model constructed, the financial dimension accounted for the largest proportion of the four dimensions, but the financial dimension of this evaluation is only qualified, indicating that W company's financial performance and goals in 2018 still have a certain gap. The sales revenue growth rate evaluation results are excellent, indicating that W company's 2018 annual sales revenue has been greatly improved compared with last year, but the sales net profit rate and cost expense rate are only at the qualified level, indicating that the company's profitability needs to be improved.

b) Customer dimension: W company has performed well in the customer dimension, and the market share evaluation result is excellent, indicating that $\mathrm{W}$ company has a good brand reputation; but its customer growth rate is only qualified, W company should identify customer needs from the customer's point of view, research and development More products that meet customer requirements and attract more customers.

c) Internal management process dimensions: W company's overall performance in the internal process dimension is good, but the evaluation results of the project quality and the owner's complaint resolution rate are all qualified. For W company, when carrying out the project construction, we must not only pursue speed, but also must guarantee the quality of the project. Improve the operation of all aspects of internal processes.

d) Learning and growth dimensions: The evaluation results of $\mathrm{W}$ company in learning and growth dimension are good, and the proportion of employee training is only qualified. W company should strengthen the training of employees and improve the quality and professional ability of employees, especially in the light asset operation mode, the human resources of the enterprise is an important light asset resource for an enterprise.

\section{B. Company Light Asset Operation Optimization Proposal}

According to the above analysis of W company's 2018 annual business performance evaluation results, combined with the characteristics of real estate enterprise light asset operation, the following suggestions are proposed for W company's light asset operation: deepen cooperative development, improve profitability; expand brand influence and accelerate brand Output; promote diversification of financing, ease corporate financing pressure; strengthen internal operations management, and lay a good foundation for light asset operations.
Based on the research on the performance evaluation of traditional real estate enterprises, this paper analyzes the current status of real estate enterprises in China and the current status of light assets operations. On this basis, based on the current lack of performance evaluation of real estate enterprises in China, combined with light asset operations. Based on the characteristics of the model, a performance evaluation index system based on balanced scorecard is constructed. Combined with the final comprehensive evaluation method, the performance evaluation model of real estate light assets operation in China is built and the model is used for empirical analysis.

\section{REFERENCES}

[1] Amit R. and Schoemaker J. H. Strategic Assets and Organizational Rents [J]. Strategic Management Journal 1993,(14):33-46.

[2] Sun Li, Zhu Wuxiang. Light Asset Operation [M]. Beijing:China Social Sciences Press,2003: 2.

[3] Xu Chunyou. Human Resource Management and Light Asset Operation [J]. Economist,2005, (02):129-130.

[4] Lu Shuang, Li Ning. Analysis of the Mode of "Light Assets Operation" [J]. Commodity and Quality,2010(6): 31.

[5] Chen Fangyong. Four Mode Choices of Real Estate "Light Assets" [J]. China Real Estate, 2016,(05):44-45.

[6] Jayoung Sohn,Chun-Hung (Hugo) Tang,Soo Cheong (Shawn) Jang. Does the Asset-light and Fee-Oriented Strategy Create Value? [J]. International Journal of Hospitality Management, 2013(32): 270 -277.

[7] Wang Zhihong. On the Variant of Balanced Scorecard [J]. Science \& Technology and Industry, 2015(1): 15-17.

[8] Zhang Yinhua. Research on Enterprise Performance Evaluation Based on Balanced Scorecard [J]. Management World,2014(4):101-102.

[9] Shen Xiang. Application of Balanced Scorecard Method in Performance Evaluation of Real Estate Development Enterprises in China [D]. Hefei University of Technology, 2008.

[10] Yan Fuhai, Enterprise Risk Management and Performance Evaluation Integration: Based on Balanced Scorecard Research [J]. China Chief Accountant, 2014, (8):101-102. 